\title{
Notes
}

\section{The Universal and the Status of Genera-Species Division in Clement of Alexandria}

\author{
Dmitry Biriukov \\ National Research University Higher School of Economics, \\ Saint Petersburg State University of Aerospace Instrumentation \\ dbirjuk@gmail.com
}

\begin{abstract}
In this paper I will defend an interpretation of Clement of Alexandria's teaching about categories, according to which the categories apply only to the material world, but not to intelligible and divine reality. I draw the parallel between Clement's theory and a corresponding doctrine offered by Eunomius, the leader of Arianism in the second half of the fourth century, which he developed as a reaction to the Nicaean horizontal discourse of Triadology.
\end{abstract}

\section{Keywords}

universals - genera-species division - categories - Middle Platonism

In this essay, I aim to briefly outline the theory of universals in Clement of Alexandria, and by doing so, I will point out certain features of his teaching that are important for subsequent Eastern Christian thought.

* The present study is a part of a larger project Nr 16-18-10202, "History of the Logical and Philosophical Ideas in Byzantine Philosophy and Theology", implemented with a financial support of the Russian Science Foundation. 
In the eighth book of Stromata Clement of Alexandria focuses on the theme of scientific knowledge ( $\left.\dot{\varepsilon} \pi \sigma \tau \eta \mu \circ v \varkappa \dot{\eta} \theta \varepsilon \omega p^{\prime} \alpha\right) .{ }^{1}$ Clement says that such knowledge is achieved through a scientific demonstration $(\dot{\alpha} \pi \delta ́ \delta \varepsilon ı \xi ı),{ }^{2}$ which is a speech that reduces the question under discussion to the unprovable origins ( $\alpha p x \alpha i)$ which we normally take for granted; the demonstration is based on true, observable, generally accepted, accurately known premises. ${ }^{3}$ Demonstration serves to indicate if there is a thing, what it is (what is its essence) and by what means it is. ${ }^{4}$

Clement of Alexandria pays particular attention to the process of division

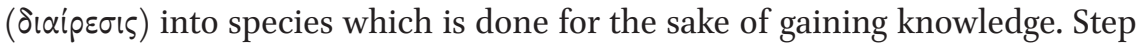
by step the division leads to something simple and indivisible, thus clarifying a subject. In this context Clement touches upon the theme of categories. Clement says that species are characterized by identity and difference; ${ }^{5}$ after division, each species falls into one of the following ten categories (however, these are not genera for these species): essence, quantity, quality, relation, position, possession, "where", "when", action, and affection (suffering). ${ }^{6}$ Further, Clement, explaining the principle of demonstration, develops a theory that classifies things and thoughts in accordance with categories. He distinguishes between things ( $\tau \dot{\alpha} \dot{v} \pi \circ x \varepsilon i \mu \varepsilon v \alpha \pi \rho \dot{\gamma} \gamma \mu \alpha \tau \alpha$ ), thoughts ( $\tau \dot{\alpha}$ voń $\mu \alpha \tau \alpha)$ and names ( $\tau \dot{\alpha}$ óvó $\mu \alpha \tau \alpha)$. Thoughts are imprints and likenesses of things, while names are symbols of thoughts and as such are correlated with thoughts. The resemblance of men's thoughts about the same things and the possibility of understanding between people arises from the fact that things make similar imprints on human souls. However, the names of the things (i.e. words) can vary depending on a language. ${ }^{7}$

Clement shares the Aristotelian premise that science is impossible with respect to the individual and possible only regarding the general. ${ }^{8}$ Clement points out that the vast number of individual things and names can be grouped

1 Stromata 8 I 1.3ff., Clemens Alexandrinus dritter Band: Stromata Buch VII und VIII, ed. O. Stählin, Leipzig, 1909, p. 80.

2 Stromata 8 III 5.1ff., Clemens Alexandrinus dritter Band, p. 82.

3 About the Aristotelian and Galenic premises of the demonstration concept in Clement see: M. Havrda, "Galenus Christianus? The Doctrine of Demonstration in Stromata VIII and the Question of its Source," Vigiliae Christianae, 65 (2011), pp. 343-375.

4 Stromata 8 VI 17.8.2-4, Clemens Alexandrinus dritter Band, pp. 90-91.

5 See: Plato, Sophist 254d14-e1.

6 Stromata 8 VI 20-21, Clemens Alexandrinus dritter Band, pp. 90-91; Stromata 8 VIII 23-24, Ibid., pp. 94-95.

7 Stromata 8 viII 23, Clemens Alexandrinus dritter Band, p. 94.

8 See: Aristotle, Metaphysica B4 999a26-29. 
under certain common elements ( $\tau \dot{\alpha} \varkappa \alpha \theta 0 \lambda \iota x \dot{\alpha} \sigma \tau \circ \iota \chi \varepsilon i \alpha)$. Therefore, according to Clement, the names can be boiled down to the twenty four letters of the alphabet, ${ }^{9}$ while the things that we want to investigate can be led up with the

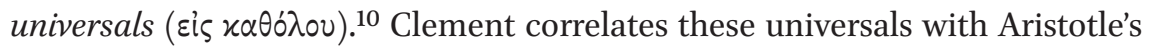
ten categories, which he considers to be means of expression ( $\left.\tau \dot{\alpha} \lambda \varepsilon \gamma \dot{o}^{\mu} \mu v \alpha\right)$. Clements calls these categories the elements of things in the matter which

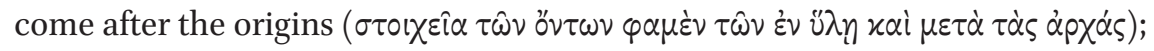
elements which are apprehended by reason $\left(\lambda \hat{o}^{\gamma} \omega\right)$, contrary to immaterial beings $(\tau \dot{\alpha} \alpha \dot{\nu} \nu \lambda)$ which are comprehended by mind $(\nu \hat{\omega}) .{ }^{11}$ According to Havrda, ${ }^{12}$ Clement speaks about the categories as elements ( $\sigma \tau \circ \chi \chi \varepsilon \hat{i}$ V) of things, assuming that those are the most basic genera for boiling down material objects to them. With respect to the above mentioned origins, Zhyrkova ${ }^{13}$ claims that these origins are acknowledged universal principles of demonstration, which we can find in Stromata. ${ }^{14}$ These origins are understood in an epistemological sense which helps us to construct a representation of sentient things. At the same time Havrda ${ }^{15}$ refers to Galen's distinction between "elements" as the final point of the genera-species division and clarifying their "origins" as a nonquality substrate and also as pure qualities. ${ }^{16}$

Havrda keeps in mind the opposition suggested by Clement between the immaterial beings ( $\tau \dot{\alpha} \alpha \ddot{\alpha} v \lambda \alpha$ ), which are comprehended by mind, and the categories understood as elements of things in matter, as well as Clement's words that definitions are not definitions of ideas. ${ }^{17}$ With these connections in mind, Havrda $^{18}$ sees in that (however, it is our opinion that he does this without sufficient grounds) the traces of the theory of universals expressed by Clement in the eighth book of Stromata which were typical for a Platonic school of Clement's times. According to this theory, there is a distinction between the forms

9 See: Plato, Philebus $18 \mathrm{~b} 3-\mathrm{d} 2$.

$10 \quad$ Stromata 8 viII 23.2-3, Clemens Alexandrinus dritter Band, p. 94.

11 Stromata 8 viII 23.6, Clemens Alexandrinus dritter Band, p. 95.

12 Havrda, "Categories in Stromata viı", p. 206.

13 A. Zhyrkova, "Reconstructing Clement of Alexandria's Doctrine of Categories," in: Conversations Platonic and Neoplatonic: Intellect, Soul, and Nature, eds. J. Finamore and R. Berchman, Sankt Augustin, 2010, p. 151.

Stromata 2 II 9.5.1-6.1; 2 IV 13.4.1-3, Clemens Alexandrinus zweiter Band: Stromata Buch I-VI, ed. O. Stählin, Leipzig, 1906, pp. 118, 119 .

15 Havrda, "Categories in Stromata VIII," pp. 206-207.

16 Galen, In Hippocratis de natura hominis librum commentarii, Galeni Opera Omnia, 20 vols., ed. C. Kühn, Leipzig, 1819-1833, vol. 15, p. 30.7ff.

17 Stromata 8 vi 19.2, Clemens Alexandrinus dritter Band, pp. 91-92.

18 Havrda, “Categories in Stromata viII", p. 208, cf. pp. 220, 222. 
in the things and intelligible forms, where the latter is the basis for knowing the former. According to Havrda's hypothesis, ${ }^{19}$ Clement learned this theory through the Galenic tradition. On the contrary, Zhyrkova sees in the eighth book of Stromata the theory of universals (universal categories), which has its origin in the legacy of Antiochus of Ascalon. According to the theory universals come about from the generalization principle of sentient experience. ${ }^{20}$

As Zhyrkova notes, ${ }^{21}$ Clement's description of categories as elements of things "in matter" is close to the widespread treatment in middle Platonism ${ }^{22}$ and in Philo ${ }^{23}$ of Aristotle's categories as utterances that can only refer to the sensory world, but not to the intelligible (and Divine) reality.

This position offered by Zhyrkova can be strengthened by the following observations. First, this understanding of the categories by Clement is in accordance with his claims that ideas in the intelligible cosmos are models for genera and species in the sentient cosmos; ${ }^{24}$ meaning that genera and species refer exactly to the sensual reality (genus and species are analogues of the secondary substance within the Aristotelian categories). Secondly, it correlates with the position expressed by Clement that definitions cannot be attached to ideas $^{25}$ (definition is an essential feature of the Aristotelian understanding of the secondary substance category). Thirdly, this understanding of Clement's teaching on categories is confirmed by the claim from Stromata 5 XII 81.5, ${ }^{26}$ where he says that God is ineffable in words, neither being a genus, nor a distinction, nor a species, nor an indivisible (individual), nor a number or some-

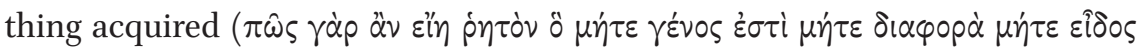

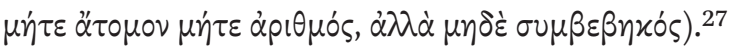

19 Havrda, “Categories in Stromata viII", pp. 222-225.

20 Zhyrkova, "Reconstructing Clement of Alexandria's Doctrine of Categories", p. 152.

21 Ibid., p. 150; Idem, "The Doctrine of Categories in Neoplatonism," in: Being or Good? Metamorphoses of Neoplatonism, ed. A. Kijewska, Lublin, 2004, p. 85, n. 2.

22 Alcinous, Epitome 4.8, Alcinoos, Enseignement des doctrines de Platon, transl. P. Louis, ed. J. Whittaker, Paris, 1990, p. 156.21ff.; 10.4, Ibid., p. 165.5ff.

23 De Decalogo 30-31, especially 30: “... categories - in the nature ( $\dot{\varepsilon} \nu \tau \hat{\eta} \varphi v ́ \sigma \varepsilon \iota)$ ".

24 Stromata 5 XIV 93.4-94.2, Clemens Alexandrinus zweiter Band, pp. 387-388.

25 Stromata 8 VI 19.2, Clemens Alexandrinus dritter Band, pp. 91-92.

26 Clemens Alexandrinus zweiter Band, p. 380.

27 Referring to Alcinous (Epitome 10.4, Alcinoos, Enseignement, p. 165.6), Mansfeld reasonably connects the middle Platonic doctrine with Clement's conception that God is not a part of that genera-species division. See: J. Mansfeld, "Substance, Being and Division in Middle Platonist and Later Aristotelian Contexts (Excurs)," in: Idem, Heresiography in context: Hippolytus' Elenchos as a source for Greek philosophy, Leiden, Boston, 1992, pp. 80, 84. 
It seems important that the aforementioned understanding of Aristotelian categories and the sphere of application of genera-species discourse, which we see in Clement's oeuvre, corresponds to the teaching about categories offered by Eunomius the leader of the Arian movement in forth century AD. Eunomius developed this teaching as a response to the horizontal discourse of Triadology, which his adversary Basil of Caesarea put forward. According to my reconstruction of Eunomius' argument, ${ }^{28}$ he thought that the higher in the taxonomy of being one goes, the lower the possibility of the horizontal generality (understood in the sense of relation between genera or species toward an individual). For a corporeal entity this generality is possible in the proper sense. While for an incorporeal being - intelligent or angelic powers - the horizontal generality is possible in a much more limited way. There is a single kind of nature for each angelic naming, but there is no general nature with regard to the angelic beings as such. With regard to the higher triad - God the Father, the Son and the Holy Spirit - the discourse of generality understood in the horizontal sense is forbidden, and in this realm there are only entities that are unique in their form.

Thus, one can speak about a similarity between the principles of the categories of Clement of Alexandria and Eunomius: ${ }^{29}$ in the teachings of each of these authors it is supposed that the genera-species discourse in its proper sense applies only to the things of the material world. Accordingly, they

28 D. Biriukov, "The Beginning of the Debate on the Universals in Byzantine Philosophy and Its Historical and Philosophical Context," cas working paper series. Advanced Academia Program (Centre for Advanced Studies Sofia), (2012-2014), 6, pp. 3-16.

29 Another point of the intersection between Clement's and Eunomius' teachings is the idea of time as the movement of celestial bodies. Such a specific idea of time - which has been little studied so far - is found in Clement's Proprepticus IV 63.1 (Clemens Alexandrinus erster Band: Proprepticus und Paedogogus, ed. O. Stählin, Leipzig, 1905, p. 48), where Clem-

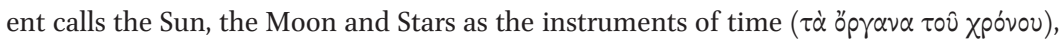
and in X 102.1, where he says that the Sun and the Moon govern the years, days and times. Likewise, Eunomius, in his Apology, speaking about God the Father as the Organizer of time and above time, makes a digression and speaks about the nature of time as of the movement of Stars (Liber Apologeticus 10; with respect to this concept of time in Eunomius, see: R. Vaggione, Eunomius of Cyzicus and the Nicene Revolution, Oxford, 2000, pp. 142-143; J. Calahhan, "Basil Caesarea a New Source for St Augustine's Theory of Time," Harvard Studies in Classical Philology, 63 (1958), p. 439; B. Sesboüé, "Notes," in: Basile de Césarée, Contre Eunome, suivi de Eunome, Apologie, T. 2, introd., trad. et notes de B. Sesboüé, avec la collab. pour le texte et l'introd. critiques de G.M. de Durand et L. Doutreleau, Paris, 1983 (SC 305), p. 255, n. 2). In its turn this understanding obviously can be traced back to the Biblical text (Gen. 1:14), can also be found in Philo, Quaestiones in Genesim 26, Legum Allegoriae I 2 and has numerous parallels in ancient philosophical tradition. 
explicitly assert that this discourse is forbidden in relation to Divine. This principle played an important role in the Arian controversy of forth century. However, we have noted that it finds an earlier manifestation in Clement of Alexandria. This gives grounds to speak about the prerequisites of the Arian argumentation against the position of the Niceans regarding the applicability of the horizontal discourse of the community to the Trinity in the preceding Christian tradition. 